\title{
POLITIK HUKUM KEDUDUKAN PERPPU (PERATURAN PEMERINTAH PENGGANTI UNDANG-UNDANG) SEBAGAI HUKUM PROGRESIF KETATANEGARAAN INDONESIA (BERDASARKAN TEORI CHEK AND BALANCES)
}

\begin{abstract}
Jufri Hardianto Zulfan
Paralegal pada Law Firm Darma-Syahriany and Partners

JI. Soekarno-Hatta no. 111.E Pekanbaru

Email: jufrihardianto01@gmail.com

Abstrack

The existence of progressive law is needed by the state to te make law as the commander of justice and to rely on welfare enforcement, the presence of progressive law wiil be able to accommodate and respond to the current problems of a society into a breaker and a solution that calms the situation. The existence or existence of government regulations in lieu of these laws will be in a straight line with the contents of the Perppu with the reality of law in action that runs in the community, because the Perppu may be issued based on the interpretation of the government unilaterally without the public or other agencies not getting adequate information related to the reasons for the enactment of the Perppu, this is despite the fact that the Perppu can be classified as progressive law, but its exixtence is strongly influenced by legal politics or political and political bargaining from the government.
\end{abstract}

Keywords: Progressive Law, Political, Perppu

\begin{abstract}
Abstrak
Keberadaan hukum progresif sangat dibutuhkan oleh negara yang menjadikan hukum sebagai panglima keadilan dan penyandaran penegakan kesejahteraan, kehadiran hukum progresif akan mampu menampung dan menjawab persoalan-persoalan kekinian suatu masyarakat menjadi pemutus dan solusi yang menenangkan keadaan. Eksistensi ataupun keberadaan Peraturan Pemerintah Pengganti UndangUndang tersebut akan bergaris lurus dengan isi dari Perppu tersebut dengan kenyataan Law In Action yang berjalan dimasyarakat, karena Perppu bisa jadi dikeluarkan berdasarkan penafsiran dari pemerintah sepihak tampa masyarakat ataupun instansi lain tidak mendapatkan informasi yang memadai terkait dengan alasan-alasan pemberlakuan Perppu tersebut, hal inilah meskipun Perppu dapat di golongkan termasuk kedalam hukum progresif akan tetapi eksistensi nya sangat dipengaruhi oleh politik hukum atau bargaining political dan political wiil dari pemerintah tersebut.
\end{abstract}

Kata Kunci: Hukum Progresif, Politik, Perppu 


\section{PENDAHULUAN}

Pembahasan tentang negara hukum akan selalu bersanding dengan politik, hal ini dikarenakan di dalam pengertian politik secara implisit tercakup unsur kekuasaan, oleh karena pada politik hakikatnya merupakan seni untuk membina kekuasaan. ${ }^{1}$ Baik buruknya kekuasaan senantiasa harus diukur dengan kegunaannya untuk suatu tujuan yang telah ditentukan atau didasari oleh masyarakat terlebih dahulu. Kekuasaan selalu ada di dalam setiap masyarakat baik yang masih sederhana maupun yang sudah kompleks susunannya. ${ }^{2}$

Negara Hukum Indonesia, setelah dilakukan amandemen terhadap Undang-Undang Dasar 1945 sebanyak empat kali yaitu amandemen pertama terjadi dan disahkan pada tanggal 19 Oktober 1999, amandemen kedua disahkan pada tanggal 18 Agustus 2000, amandemen ketiga disahkan pada tanggal 10 November 2001 dan kemudian amandemen keempat disahkan pada tanggal 10 Agustus 2002. Sebagai akibat dan konsekuensi dari adanya amandemen tersebut adalah banyak nya terdapat perubahan struktur ketatanegaraan Indonesia, baik itu mengenai

\footnotetext{
${ }^{1}$ Maka jika muncul suatu pertanyaan tentang manakah yang lebih unggul atau dominan (supreme) di antara hukum dan politik. Maka jawabannya adalah tergantung pada sikuens (urutan) proses terjadi dan berlakunya hal tersebut. Berarti hukum sewaktuwaktu lebih dahulu dari politik, misalnya dibuatnya Undang-Undang Dasar, Ialu kemudian disusul dengan adanya GBHN (Garis-Garis Besar Haluan Negara). Kemudian GBHN ini pula berfungsi dan berkedudukan supremasi politik dalam rancangan, perumusan dan pembuatan suatu undang-undang. Maka jelaslah bahwa kedudukan hukum lebih dominan dari pada politik karena dalam kontes ini politik mesti mengikuti alur aturan hukum tersebut. Seperti itulah gambaran yang terjadi baik ditingkat pusat ataupun ditingkat daerah. Adakalanya hukum determinan atas politik dan ada pula masany politik determinan atas hukum.

${ }^{2}$ Mayarakat pada hakekatnya terdiri dari berbagai lembaga masyarakat yang saling mempengaruhi dan susunan lembaga kemasyarakatan tadi berdasarkan kepada suatu pola tertentu. Suatu perubahan sosial biasanya dimulai pada suatu lembaga kemasyarakatan tertentu dan perubahyan tadi akan menjalar kepada lembaga-lembaga kemasyarakatan lain. Lebih lanjut lihat: Soerjono Soekanto, Beberapa Permasalahan Hukum dalam Kerangka Pembangunan di Indonesia, UI Press, Jakarta, 1982, hlm. 158162. Dalam Adi Sulistiyono, Negara Hukum: Kekuasaan, konsep dan Paradigma Moral, UNS Press, Cet-2, Surakarta, 2008, hlm. 11
} 
kelembagaan, kewenangan serta juga tidak luput dengan adanya perubahan terhadap berbagai hal kewenangan seorang Presiden ${ }^{3}$.

Diantara kewenangan kewenangan Presiden adalah membuat Perppu (Peraturan Pemerintah Pengganti Undang-Undang) dengan berbagai syarat dan ketentuan berlakunya serta dengan berbagai keadaaan agar peraturan tersebut dapat dianggap sebagai upaya konkrit terhadap situasi terkini yang dialami suatu negara (negara dalam keadaan krisis), namun timbulnya pertanyaan adalah apakah kehadiran Perppu tersebut merupakan salah satu dari solusi pemecahan masalah yang dihadapi bangsa ini, apakah Perppu tersebut dalam dianggap sebagai salah satu bentuk dari hukum Progresif yang merespon situasi dan kondisi politik dan keamanan suatu negara, atau apakah Perppu tersebut hanya bentuk dari politik massif pihak eksekutif untuk melanggengkan kekuasaanya, selain hal tersebut keberadaan Perppu tersebut untuk melihat eksis atau tidak nya dapat dilihat bagaiamana akibat setelah diterbitkan aturan tersebut dan hal ini dapat dilihat dari Law In Action masyarakat secara umum disuatu negara.

Penellitian ini bertujuan untuk memberikan pencerahan terkait dengan potensi kemamfaat hukum Perppu (Peraturan Pemerintah Pengganti Undang-Undang) sebagai salah satu hukum progresif yang harus dilaksanakan dengan baik yang tentunya dengan

${ }^{3}$ Karena memang pemicu aksi demonstrasi besar-besaran terjadi pada masa pemerintahan Presiden Soeharto yang dipandang terlalu memiliki power full atas pemerintahan nya. Sedangkan menurut Tjipta Lesmana dalam bukunya menuliskan, aksi-aksi rakyat yang semula bermotifkan ekonomi berkembang menjadi aksi politik, yaitu menuntut pengunduran diri Seoharto. Gejolak politik ini terkait juga dengan situasi perekonomian yang semakin memburuk akibat krisis moneter yang menghantam sebagian kawasan Asia seperti Thailand, Korea Selatan, dan Filipina, disamping Indonesia. Menghadapi krisis moneter yang tiba-tiba, Indonesia terpaksa minta bantuan kepada Badan Moneter Internasional (IMF). Dan resep IMF untuk mengobati perekonomian yang dinilai sakit dimana-mana tidak berbeda, yaitu mendesak negara yang bersangkutan untuk melaksanakan kebijakan mengencangkan ikat pinggang (thigh money policy), antara lain, dengan menaikkan harga BBM, tarif listrik, telepon, dan sebagainya. Lebih lengkap lihat, Tjipta Lesmana, Dari soekarno Sampai SBY, Intrik dan Lobi Politik Para Penguasa Gramedia, Jakarta, Cet-3, 2009, hlm. 117-118 
mempertimbangkan asas-asas kemamfaatan hukum, keadilan dan kepastian hukum.

Diharapkan hasil penelitian ini bermanfaat untuk kalangan akademisi dan praktisi hukum serta pemerintah eksekutif pada khususnya, serta hendaknya bermamfaat pula untuk semua kalangan masyarakat secara umum agar negara Indonesia ini lebih baik kedepannya.

\section{METODE PENELITIAN}

Agar memperoleh data yang akurat dan relevan dengan penelitian ini, maka penulis menggunakan metode sebagai berikut:

\section{Jenis dan Sifat Penelitian}

Penelitian ini adalah peneltian normatif. Penelitian hukum normatif sendiri adalah penelitian hukum yang dilakukan dengan cara meneliti bahan pustaka atau data sekunder. ${ }^{4}$

\section{Sifat Penelitian}

Sifat penelitian dalam penyusunan penelitian ini adalah deskriptif-analitik, ${ }^{5}$ yakni suatu usaha untuk mengumpulkan dan menyusun suatu data, kemudian dianalisis dan ditafsirkan. ${ }^{6}$ Artinya penyusun memaparkan dan menjelaskan hal-hal yang berkaitan dengan "Politik Hukum Kedudukan Perppu (Peraturan Pemerintah Pengganti Undang-Undang) Sebagai Hukum Progresif Ketatanegaraan Indonesia."

\section{Sumber Data}

Pada penulisan yang dilakukan adalah model studi pustaka (library research), yang dimaksud dengan studi kepustakaan adalah pengkajian informasi tertulis mengenai hukum yang berasal

${ }^{4}$ Salim HS dan Erlies Septiana Nurbani, Penerapan Teori Hukum Pada Penelitian Tesis dan Desertasi, Jakarta, Raja Grafindo, 2013, hlm. 12

${ }^{5}$ Mukhtar menuliskan, tesis adalah karya ilmiah yang dibuat secara mendalam (elaboratif). Lihat Mukhtar, Bimbingan Skripsi, Tesis dan Artikel IImiah, Gaung Persada Press, Cet-2, Jakarta, 2009

${ }^{6}$ Winarno Surahcmad, Pengantar Penelitian IImiah, (Dasar, Metode, Teknik), Tarsito,Bandung, 1990, hlm. 139-140 

Jufri

dari berbagai sumber dan dipublikasikan secara luas serta dibutuhkan dalam penelitian hukum normatif, ${ }^{7}$ yakni penulisan yang didasarkan pada data-data yang dijadikan objek penelitian, seperti peraturan perundang-undangan, buku-buku pustaka, majalah, artikel, surat kabar, bulletin, tentang segala permasalahan yang sesuai dengan tesis ini yang akan disusun dan dikaji secara komprehensif. ${ }^{8}$ Apabila dilihat dari sisi kekuatan mengikatnya, data sekunder dibidang hukum dapat dibedakan menjadi:

a) Bahan-bahan hukum primer, meliputi: Undang-Undang Dasar Negara Republik Indonesia Tahun 1945, dan Undang-Undang. ${ }^{9}$

b) Bahan-bahan hukum sekunder adalah bahan-bahan hukum yang memberikan penjelasan atau membahas lebih lanjut halhal yang telah diteliti pada bahan-bahan hukum primer.

c) Bahan-bahan hukum tersier adalah bahan-bahan hukum tambahan, diluar bahan hukum primer dan sekunder. Meliputi, bahan hukum yang diperoleh dari teks, jurnal, kasus-kasus, desertasi, hasil penelitian yang berkaitan dengan masalah yang diteliti.

\section{Analisis Data}

Data yang telah dikelola akan dianalisis secara kualitatif dengan menggunakan instrument analisis induktif. Pola pikir induktif adalah pola pikir yang berpijak pada fakta yang bersifat khusus, kemudian diteliti dan kemudian ditemukan pemecahan persolan bersifat umum. Metode analisis yang digunakan adalah

7 Abdul Kadir Muhammad, Hukum Dan Penelitian Hukum, Citra Aditia Bakti, Bandung, 2004, hlm. 81

${ }^{8}$ Widodo Dwi Putro, menuliskan dalam tulisan berjudul "Mengkritisi Positivisme Hukum: Langkah Awal Memasuki Diskursus Metodologis Dalam Penelitian Hukum", bahwa Katup pembuka wacana tersebut (penelitian hukum normative dan empiris) yang mendorong munculnya pertikaian metodologis dalam penelitian hukum, yang lazim dikenal dengan penelitian hukum empiris versus normative menurutnya adalah bermula dari munculnya aliran positivism di Eropa, terutama setelah meletusnya Revolusi Industri di Inggris dan Revolusi Borjuis di Perancis pada pertengahan abad ke-18. Lihat, Sulistyowati Irianto dan Shidarta, Metode Penelitian Hukum Konstelasi dan Refleksi, Yayasan Obor Indonesia, Jakarta, 2009, hlm. 3

${ }^{9}$ Zainuddin Ali, Metode Penelitian Hukum, Sinar Grafika, Jakarta, 2009, hlm. 47 
analisis kualitatif, yaitu: metode analisis yang pada dasarnya menggunakan pemikiran logis, analisis dengan logikan, dengan induksi, analogi/interpretasi, komparasi, dan sejenis itu. Metode berfikir yang dipergunakan adalah metode induktif, yaitu dari data/fakta menuju ke tingkat abstraksi yang lebih tinggi, termasuk juga melakukan sintesis dan mengembankan teori (bila diperlukan dan datanya menunjang). ${ }^{10}$ Data Sekunder, ${ }^{11}$ Data Sekunder diperoleh dari bahan pustaka dan dokumentasi yang merupakan data dasar dalam penelitian hukum normatif, yang menjadi pijakan untuk menjawab permasalahan dan tujuan penelitian.

\section{PEMBAHASAN}

\section{Hukum Positif Dalam Perspektif Hukum Progresif}

IImu dan teori-teori positivistis menjadi dominan karena memberi respon terhadap kehausan praktik untuk memperoleh tuntunan dan “legitimasi akademis". Dalam keadaan yang demikian itu terdapat resiko, bahwa masyarakat atau publik akan kurang mendapatkan pencerahan yang baik ${ }^{12}$. Di Indonesia, mempunyai banyak contoh tentang kegagalan hukum untuk membawa koruptor ke penjara oleh pengadilan. Hampir sama dengan yang terjadi di Amerika, kegagalana tersebut disebabkan oleh sikap submisif terhadap kelengkapan hukum yang ada, seperti prosedur, doktrin dan asas. Akibatnya, hukum justru bisa menjadi safe heaven bagi para koruptor. Dilihat dari sudut hukum progresif maka caracara dan praktik berhukum seperti itu sudah tergolong kontra-progresif ${ }^{13}$.

10 Sanapiah Faisal, Penelitian Kualitatif: Dasar-Dasar dan Aplikasi, Y A 3 , Malang, 1999, hal. 39

${ }_{11}$ Menurut Amiruddin dan Zainal Asikin dalam tulisannya menuliskan, bagi penellitian hukum normative yang hanya mengenal data sekunder saja, yang terdiri: bahan hukum primer, bahan hukum sekunder, dan bahan hukum tersier, maka dalam mengolah dan menganalisis bahan hukum tersebut tidak bisa melepaskan diri dari berbagai penafsiran yang dikenal dalam ilmu hukum. Lihat, Amiruddin dan Zainal Asikin, Pengantar Metode Penelitian Hukum, Rajawali Pers, Cet-6, Jakarta, 2012, hlm. 163

12 Qodri Azizy dkk, "Menggagas Hukum Progresif Indonesia”, Pustaka Pelajar, Jakarta, 2006, hlm. 7

\footnotetext{
${ }_{13}$ Ibid, hlm 8
} 
Dibandingkan dengan ilmu hukum praktis, ilmu hukum progresif sebetulnya tidak sama sekali gagal atau tidak bisa memberi tuntutan terhadap praktik. Perbedaan terletak pada ilmu hukum praktis yang menggunakan paradigma peraturan (rule), sedang ilmu hukum progresif memakai paradigma manusia (people). Penerimaan paradigma manusia tersebut membawa ilmu hukum progresif untuk memedulikan faktor perilaku (behavior, experience). Dalam bahasa Holmes, logika peraturan disempurnakan dengan logika pengalaman. Bagi ilmu hukum progresif, hukum adalah untuk manusia, sedangkan pada ilmu hukum praktis manusia adalah lebih untuk hukum dan logika hukum. Di sinilah letak pencerahan oleh ilmu hukum progresif ${ }^{14}$.

\section{Kekuasaan Presiden Berdasarkan Undang-Undang Dasar 1945}

Tepatnya dalam Bab III tentang Kekuasaan Pemerintahan Negara, yang terpenting dalam hal ini adalah apa yang telah ditentukan, diantaranya:

1. Dalam Undang-Undang Dasar 1945 Pasal 4 ayat (1) yaitu yang berbunyi "Presiden memegang kekuasaan pemerintahan menurut Undang-Undang Dasar." Dari pernyataan ini jelas bahwa kekuasaan pemerintahan dipegang oleh seorang Presiden

2. Seseorang yang mengatur tata pemerintahan, seseorang yang memegang kendali serta panglima tertinggi Angkatan Darat, Angkatan Laut, Angkatan Udara. Lihat Undang-Undang Dasar 1945 Pasal 10 menyatakan "Presiden memegang kekuasaan yang tertinggi atas Angkatan Darat, Angkatan Laut, Angkatan Udara."

3. Seseorang yang menyatakan keadaan bahaya atas Negara, lihat Undang-Undang Dasar 1945 Pasal 12 yang berbunyi "Presiden menyatakan bahaya. Syarat-syarat dan akibatnya keadaan bahaya ditetapkan dengan undang-undang.

${ }^{14}$ Ibid., hlm 9 
4. Seseorang yang memiliki kewengan mengangkat duta dan konsul, lihat Undang-Undang Dasar 1945 Pasal 13 ayat (1) menyatakan "Presiden mengangkat duta dan konsul."

5. Seseorang yang kuasa untuk memberikan grasi, rehabilitasi, amnesti dan abolisi, lihat Undang-Undang Dasar 1945 Pasal 14 ayat (1) dan (2) menyatakan "Presdien memberi grasi dan rehabilitasi dengan memperhatikan pertimbangan Mahkamah Agung dan ayat (2) Presiden memberikan amnesty dan abolisi dengan memperhatikan pertimbangan Dewan Perwakilan Rakyat."

6. Seseorang yang dapat membentuk dewan nasehat untuk memberikan pertimbangan dan nasihat kepadanya, lihat UndangUndang Dasar 1945 Pasal 16 menyatakan, "Presiden membentuk suatu dewan pertimbangan yang bertugas memberikan nasihat dan pertimbangan kepada Presiden, yang selanjutnya diatur dengan undang-undang."

7. Seseorang yang menentukan diangkat atau tidaknya suatu pejabat pemerintahan, lihat Undang-Undang Dasar 1945 bab V tentang Kementrian Negara Pasal 17 ayat (2) "menteri-mentri diangkat dan diberhentikan oleh Presiden"15.

\section{Teori Pemisahan Kekuasaan (Separation Of Power) dan Pembagian Kekuasaan (Distribution Of Power)}

Dalam teori permasalahan yang dibahas diatas dapat melihat bahwa Undang-Undang Dasar 1945 pra-amandemen tidak memberikan ketentuan yang tegas dalam pembagian kekuasaan ${ }^{16}$. Undang-Undang

\footnotetext{
${ }^{15}$ Lebih lengkapnya lihat, Jufri Hardianto Zulfan, Dua Gelas Kopi Hitam Untuk Pak Presiden, www. Riau Realita. Com. Diakses pada tanggal 06 April 2018.

${ }^{16}$ Mencermati dengan baik dalam Undang-Undang Dasar 1945 pra amandemen membagi pasal-pasal tersendiri mengenai alat-alat perlengkapan negara dengan tidak menekankan kepada pemisahannya. Hal ini dapat dilihat dalam sistematika dari UndangUndang Dasar 1945 yang membagi dalam bab per bab, Bab III tentang Kekuasaan Pemerintahan Negara, Bab VII tentang Dewan Perwakilan Rakyat, dan, Bab IX tentang Kekuasaan Kehakiman, hal ini menjelaskan kepada kita tentang pengelompokanpengelompokan kekuasaan.
} 
Dasar 1945 hanya mengenal pemisahan kekuasaan secara formil, oleh karena itu pemisahan kekuasaan itu tidak dipertahankan secara prinsipil. Dengan kata lain Undang-Undang Dasar 1945 hanya mengenal pembagian kekuasaan (Devision Of Power) bukanlah pemisahan kekuasaan (Separation Of Power). ${ }^{17}$

Hukum progresif juga mulai mempengaruhi Undang-Undang Dasar dan perubahan-perubahannya. Sedangkan dalam pandangan Soepomo, bahwa Undang-Undang Dasar 1945 mempunyai sistem tersendiri, yaitu berdasarkan pembagian kekuasaan. Walaupun dalam pembagian kekuasaan itu setiap lembaga negara sudah mempunyai tugas tertentu, namun dalam sistem ini dimungkinkan adanya kerjasama antar lembaga negara, oleh sebab itu jelaslah bahwa Undang-Undang Dasar 1945 tidak menganut pemisahan (Separation Of Power), tetapi dalam sistem ketatanegaraan menurut Undang-Undang Dasar 1945 mengenal adanya pembagian kekuasaan sebagai berikut:

1) Pada dasarnya Undang-Undang Dasar 1945 mengenal pembagian kekuasaan;

2) Undang-Undang Dasar 1945 membagi kekuasaan kepada tiga lembaga yang diatur secara mendasar kedudukan dan fungsinya;

3) Antar lembaga negara ada kerja sama di dalam menjalankan tugasnya merupakan kekuasaan yang merdeka, bebas dari pengaruh kekuasaan lainnya, baik eksekutif maupun legislatif. Di samping itu lembaga penuntut umum (Kejaksaan Agung) yang tidak terdapat penyebutannya dalam Undang-Undang Dasar 1945. Menyikapi hal ini menurut Ismail Sunny, mengomentari, dalam suatu negara hukum yang penting bukan ada atau tidaknya Trias Politica, persoalanya adalah dapat atau tidakkah alat-alat kekuasaan negara itu dihindarkan dari praktik birokrasi dan tirani. Dan hal ini tidaklah tergantung

${ }^{17}$ Ismail Sunny, Dalam, Titik Triwulan Tutik, Pokok-Pokok Hukum Tata Negara Indonesia Pasca Amandemen UUD 1945, Cerdas Pustaka, Jakarta, hlm. 88. 
pada pemisahan kekuasaan itu sendiri, tetapi kepada adanya sendi negara demokrasi yaitu kedaulatan rakyat ${ }^{18}$.

Prinsip pemisahan kekuasaan merupakan bahwa antar lembaga negara bekerja masing-masing dan bertanggung jawab penuh atas amanah yang diembankan kepadannya, prinsip pemisahan kekuasaan juga tidak memungkinkan terjadinya saling pengawasan antar lembagalembaga negara, meskipun keberadaan lembaga-lembaga tersebut berada dalam satu negara dan bahkan walaupun bangunan sekretarian mereka berdekatan, hal ini dikarenakan tidak lain adalah karena di negara-negara yang menganut prinsip pemisahan kekuasaan dalam konstitusinya sebagai hukum tertinggi tidak menentukan dan tidak lah menyebutkan yang pada intinya menginginkan adanya saling control dan mengimbangi antar lembaga negara tersebut dan ini kita kenal dengan Prinsip Separation Of Power (Prinsip Pemisahan Kekuasaan).

Namun untuk konsep negara Indonesia, seperti telah dijelaskan sebelumnya, memang telah jelas bahwa Undang-Undang Dasar sebagai landasan hierarki ketatanegaraan yang paling menetukan bahwa, di dalam negara Indonesia lembaga-lembaga negara saling bekerja sama dan saling mengontrol antar lembaga yang satu dengan lembaga yang lainnya, hal ini tentunya tidak berarti adanya campur tangan kewenangan dari lembaga lain terhadap lembaga lainya dalam hal menjalankan tugas dan menjalakan kewenangannya, hal ini dikarenakan setiap lembaga negara yang disebutkan didalam konsitusi bersifat mandiri tidak dibawahi ataupun tidak berada dibawah suatu institusi tertentu.

Meskipun hubungan eksekutif selaku sebagai penjalankan hukum maka yudikatif memiliki kewenangan dalam mengontrol dan menghukum setiap pelaku dari pelanggar hukum dari pihak eksekutif dan bukan berarti yudikatif dengan leluasa mencampuri segala tugas dari eksekutif hubungan diantara keduanya lebih mengarah kepada kerja sama dalam

${ }^{18} \mathrm{lbid}, \mathrm{hlm} .89$ 
penegakan hukum, dalam contoh-contoh yang lain kita dapat melihat dalam Undang-Undang Dasar $1945^{19}$, diantaranya yaitu:

1. Dalam Pasal 20 ayat (2) menyatakan, setiap rancangan undangundang dibahas oleh Dewan Perwakilan Rakyat dan Presiden untuk mendapat persetujuan bersama

2. Dalam Pasal 22 ayat (1) menyatakan, hal ihwal kepentingan yang memaksa, Presiden berhak menentapkan Peraturan Pemerintah sebagai pengganti undang-undang. Dan disambung dengan ayat (2) menyatakan, Peraturan Pemerintah itu harus mendapat persetujuan Dewan Perwakilan Rakyat dalam persidangan yang berikut. Dan ayat (3) menyatakan, jika tidak mendapat persetujuan maka Peraturan Pemrintah itu harus dicabut.

3. Dan selanjutnya dapat kita lihat dalam Bab III Tentang Kekuasaan Pemerintahan, diantaranya:

a. Pasal 5 ayat (1) menyatakan, Presiden berhak mengajukan rancangan undang-undang kepada Dewan Perwakilan Rakyat.

b. Pasal 7A menyatakan, Presiden dan/atau wakil Presiden dapat diberhentikan dalam masa jabatannya oleh Majelis Permusyaratan Rakyat atas usul Dewan Perwakilan Rakyat atas usul Dewan Perwakilan Rakyat, baik apabila terbukti telah melakukan pelanggaran hukum berupa pengkhiatanan terhadap Negara, korupsi, penyuapan, tindak pidana berat lainnya, atau perbuatan tercela maupun apabila tidak terbukti tidak lagi memenuhi syarat sebagai Presiden dan/atau Wakil Presiden.

c. Pasal 7B ayat (1) menyatakan, usul pemberhentian Presiden dan/atau Wakil Presiden dapat diajukan oleh Dewan Perwakilan Rakyat kepada Majelis Permusyawaratan Rakyat hanya dengan terlebih dahulu mengajukan permintaan kepada Mahkamah Konstitusi untuk memeriksa, mengadili, dan memutus pendapat

${ }^{19}$ Lihat, Kedudukan, Sifat, dan Isi Undang-Undang Dasar 1945, Gery Ismanto, M. Alpi Syahrin dan Sri Ika Mulia, Pendidikan Pancasila, Mulia Indah Kemala, Pekanbaru, Cet Ke-2, 2013, hlm. 86-93 
Dewan Perwakilan Rakyat bahwa Presiden dan/atau wakil Presiden telah melakukan pelanggaran hukum berupa pengkhianatan terhadap negara, korupsi, penyuapan, tindak pidana berat lainnya, atau perbuatan tercela, dan/atau pendapat Presiden dan/atau Wakil Presiden tidak lagi memenuhi syarat sebagai Presiden dan/atau Wakil Presiden. Dan untuk selanjutnya dapat dilihat dalam ayat (2), (3), (4), (5), (6), (7). Yang membahas mengenai mekanisme pemberhentian Presiden dan/atau Wakil Presiden.

4. Pasal 11 ayat (1) menyatakan, Presiden dengan persetujuan Dewan Perwakilan Rakyat menyatakan perang, membuat perdamian dan perjanjian dengan negara lain dan ayat (2) menyatakan, Presiden dalam membuat perjanjian internasional lainnya yang menimbulkan akibat yang luas dan mendasar bagi kehidupan rakyat yang terkait dengan beban keuangan negara, dan/atau mengharuskan perubahan dan pembentukan undangundang harus dengan persetujuan Dewan Perwakilan Rakyat.

5. Pasal 14 ayat (1) menyatakan, Presiden memberi grasi dan rehabilitasi dengan memperhatikan pertimbangan Mahkamah Agung. Dan ayat (2) menyatakan, Presiden memberi amnesty dan abolisi dengan memperhatikan pertimbangan Dewan Perwakilan Rakyat.

Dari semua aturan-aturan yang telah disebutkan diatas menjelaskan dengan lengkap bahwa didalam konstitusi sendiri memang telah diatur untuk beberapa agenda adanya kerjasama antar lembaga negara, dan sesuai dengan pembahasan pada Bab ini adalah mengenai teori dari distribution of Power atau pembagian kekuasaan artinya walaupun lembaga-lembaga tersebut memiliki ketentuan, tugas dan wewenang masing-masing namun tetap saling mengontrol dan mengimbangi. 

Jufri

\section{Teori Saling Kontrol dan Mengimbangi (Cheks and Balances) Lembaga Negara}

Teori Cheks and Balances merupakan Prinsip-Prinsip yang dianut oleh negara-negara yang memiliki berbagai macam lembaga-lembaga negara, jika di Prancis dipelopori oleh Montesque dengan teorinya, kekuasaan negara dibagi kedalam tiga bagian besar yaitu eksekutif, legislatif dan yudikatif. Dalam perjalanannya sistem ketatanegaraan Indonesia mengalami perubahan yang sangat mendasar sejak adanya amandemen Undang-Undang Dasar 1945 yang dilakukan oleh Majelis Permusyawaratan Rakyat (MPR) pada tahun 1999 hingga tahun 2002.

Perubahan tersebut dilatarbelakangi adanya kehendak untuk menyesuaikan dan bentuk responsif kedaan kekinian dengan tujuan membangun pemerintahan yang demokratis dengan Cheks and Balances yang setara dan seimbang di antara cabang-cabang kekuasaan, mewujudkan supremasi hukum dan keadilan, serta menjamin dan melindungi hak asasi manusia ${ }^{20}$. Dalam kelembagaan negara, salah satu tujuan utama amandemen Undang-Undang Dasar 1945 adalah untuk menata keseimbangan (Cheks and Balances) antar lembaga. Hubungan itu ditata sedemikian rupa sehingga tidak terjadi pemusatan kekuasaan pada salah satu institusi negara saja ${ }^{21}$.

${ }^{20}$ Mahkamah Konstitusi, Cetak Biru: Membangun Mahkamah Konstitusi sebagai institusi Peradilan Konstitusi yang modren dan terpercaya, (Jakarta: Mahkamah Konstitusi, 2004), hal. 3. Lihat juga, Titik Triwulan Tutik, Pokok-Pokok Hukum Tata Negara Indonesia Pasca Amandemen Undang-Undang Dasar 1945, Cerdas Pustaka, Jakarta, hlm. 90.

${ }_{21}$ Hal ini membuktikan kepada khalayak umum bahwa ada dua macam karakteristik negara sebagai suatu bentuk pergaulan hidup yang tidak dimiliki oleh bentuk-bentuk pergaulan hidup lain yang bukan negara, yaitu, 1. Negara memiliki kekuasaan yang lebih tinggi dari pada bentuk-bentuk pergaulan hidup lain yang bukan negara,2. Negara memiliki kedudukan yang lebih tinggi dari pada bentuk-bentuk pergaulan hidup lain yang bukan negara. Negara sebagai suatu gejala sosial sudah menjadi perhatian manusia sejak berabad-abad lalu, Negara sebagai organisasi merupakan wadah untuk kelompok manusia yang hidup bersama dalam suatu tatanan yang terorganisasi. Lebih lengkap lihat, Hotma P. Sibue, Asas Negara Hukum, Peraturan Kebijakan dan Asas-asas Umum Pemerintahan Yang Baik, Erlangga, Jakarta, 2010, hlm. 3 
Bentuk nyata dari perubahan mendasar hasil amandemen UndangUndang Dasar 1945 adalah perbedaan yang substansial tentang kelembagaan negara menurut Undang-Undang Dasar 1945 Hasil Amandemen dengan Undang-Undang Dasar 1945, terutama yang menyangkut lembaga negara, kedudukan, wewenang, hubungan kerja, dan cara kerja lembaga yang bersangkutan serta yang lebih responsif. Berkaitan dengan lembaga negara, perubahan pertama Undang-Undang Dasar 1945 memuat pengendalian kekuasaan Presiden dan tugas serta wewenang Dewan Perwakilan Rakyat (DPR) dan Presiden dalam hal pembentukan undang-undang. Perubahan kedua Undang-Undang Dasar 1945 menata ulang keanggotaan, fungsi, hak, maupun cara pengisiannya. Perubahan ketiga, membahas ulang kedudukan dan kekuasaan Majelis Permusyawaratan Rakyat (MPR), jabatan Presiden yang berkaitan dengan tata cara pemilihan dan pemilihan secara langsung, pembentukan lembaga negara baru meliputi Mahkamah Konstitusi, Dewan Perwakilan Daerah, dan Komisi Yudisial serta pengaturan tambahan Badan Pemeriksa Keuangan (BPK). Dan perubahan keempat Undang-Undang dasar 1945, meliputi keanggotaan Majelis Permusyawaratan Rakyat (MPR), memilih Presiden dan Wakil Presiden tahap kedua dan kemungkinan Presiden/Wakil Presiden berhalangan tetap, serta kewenangan Presiden.

\section{KESIMPULAN}

Kedudukan Peraturan Pemerintahan Pengganti Undang-Undang sebagai hukum progresif dalam ketatanegaraan Indonesia, telah dibuktikan dengan tata cara dan proses lahir nya Perppu tersebut, yaitu hanya dikeluarkan ketika keadaan tertentu dan saat tertentu saja serta disesuaikan dengan peristiwa yang terjadi, dengan pendangan bahwa hukum diciptakan untuk manusia dan bukanlah manusia untuk hukum, hal ini memiliki kemiripan dengan ciri-ciri hukum progresif. Adapun pengertian hukum progresif, adalah mengubah secara cepat, melakukan pembalikan 
yang mendasar dalam teori dan praktis hukum, serta melakukan berbagai terobosan. Pembebasan tersebut di dasarkan pada prinsip bahwa hukum adalah untuk manusia dan bukan sebaliknya dan hukum itu tidak ada untuk dirinya sendiri, melainkan untuk sesuatu yang lebih luas yaitu untuk harga diri manusia, kebahagiaan, kesejahteraan, dan kemuliaan manusia. Dengan bahasa sederhana, bahwa Peraturan Pemerintah Pengganti Undang-Undang adalah salah satu bentuk dari hukum yang bersifat responsif dan tentu saja hukum ini dapat saja dapat digunakan dalam kebaikan dan juga sebaliknya untuk kepentingan tertentu.

Eksistensi Peraturan Pemerintah Pengganti Undang-Undang tersebut akan bergaris lurus dengan isi dari Perppu tersebut dan kenyataan Law In Action yang berjalan dimasyarakat, karena Perppu bisa jadi dikeluarkan berdasarkan penafsiran dan pemerintah sepihak tampa masyarakat ataupun instansi lain tidak mendapatkan informasi yang memadai terkait dengan alasan-alasan pemberlakuan Perppu tersebut, hal inilah meskipun Perppu dapat di golongkan termasuk kedalam hukum progresif akan tetapi eksistensi nya sangat dipengaruhi oleh politik hukum atau bargaining political dan political wiil dari pemerintah tersebut. Latar belakang hadirnya Perppu tersebut seharunya juga di sadari oleh masyarakat bahwa Perppu tersebut memang pantas hadir dan memang dibutuh kan untuk keadaan yang mendesak dan segera di aplikasikan agar problema-problema yang sedan terjadi dapat berkurang dan diatasi dengan baik.

\section{SARAN}

1. Sangat diperlukan oleh terutama sekali untuk pemerintahan eksekutif dalam pemahaman tentang bagaimana potensi Perppu memiliki peran yang sangat baik untuk menjadi hukum progresif yang sangat diperlukan oleh negara dalam menyesuaikan diri ataupun dalam menyelesaikan serta memberikan jalan keluar atas permasalahan terkini yang sedang dihadapi oleh negara secara 
umum, pemahaman yang baik terhadap keberadaan Perppu akan menyadarkan pemerintah bahwa kepentingan negara lebih diutamakan dari pada kepetingan golongan apalagi kepentingan pribadi

2. Para peneliti dengan lembaga penelitiannya yang menaungi para cendikiawan atau pun para akademisi harus mampu memberikan konsep hukum progresif yang baik dalam pembentukan Perppu, sehingga dengan konsep-konsep yang dirumuskan tersebut Perppu diharapkan menjadi jalan keluar bersama dan menjadi hasil kesepakatan bersama untuk solusi permasalahan kekinian dan bukan menjadikan Perppu seolah-olah menjadi alat memperlihatkan kediktatoran dalam hal ini Presiden sebagai lembaga yang diberikan kewenangan oleh konstitusi untuk menerbitkan Perppu tersebut.

\section{DAFTAR PUSTAKA}

Abdul Kadir Muhammad, Hukum Dan Penelitian Hukum, Citra Aditia Bakti, Bandung, 2004

Adi Sulistiyono, Negara Hukum: Kekuasaan, konsep dan Paradigma Moral, UNS Press, Surakarta, 2008

Gery Ismanto, M. Alpi Syahrin dan Ika Mulia, Pendidikan Pancasila, Mulia Indah Kemala, Pekanbaru, 2013

Hotma P Sibue, Asas Negara Hukum, Peraturan Kebijakan, dan AsasAsas Pemerintahan Yang Baik, Erlangga, Jakarta, 2010

Jufri Hardianto Zulfan, Dua Gelas Kopi Hitam Untuk Pak Presiden, www. Riau Realita. Com. 2018

Mahkamah Konstitusi, Cetak Biru: Membangun Mahkamah Konstitusi Sebagai Institusi Peradilan Konstitusi Yang Modren dan Terpercaya, Mahkamah Konstitusi, Jakarta, 2004

Mukhtar, Bimbingan Skripsi, Tesis dan Artikel Ilmiah, Gaung Persada Press, Jakarta, 2009

Salim HS dan Erlies Septiana Nurbani, Penerapan Teori Hukum Pada Penelitian Tesis dan Desertasi, Jakarta, Raja Grafindo, 2013

Soerjono Soekanto, Beberapa Permasalahan Hukum dalam Kerangka Pembangunan di Indonesia, UI Press, Jakarta, 1982

Tjipta Lesmana, Dari Soekarno Sampai SBY, Intrik dan Lobi Politik Para Penguasa, Gramedia, Jakarta, 2009 
Titik Triwulan Tutik, Pokok-Pokok Hukum Tata Negara Indonesia Pasca Amandemen UUD 1945, Pustaka Pelajar, Jakarta, 2008

Qodri Azizy, Dkk, Menggagas Hukum Progresif Indonesia, Pustaka Pelajar, Jakarta, 2006

Winarno Surahcmad, Pengantar Penelitian Ilmiah, (Dasar, Metode, Teknik), Tarsito,Bandung, 1990

Sulistyowati Irianto dan Shidarta, Metode Penelitian Hukum Konstelasi dan Refleksi, Yayasan Obor Indonesia, Jakarta, 2009.

Zainuddin Ali, Metode Penelitian Hukum, Sinar Grafika, Jakarta, 2009. 